NASA Technical Memorandum 86925 AIAA-85-0338

\title{
The UH-1H Helicopter Icing Flight Test Program: An Overview
}

Robert J. Shaw and G. Paul Richter Lewis Research Center Cleveland, Ohio

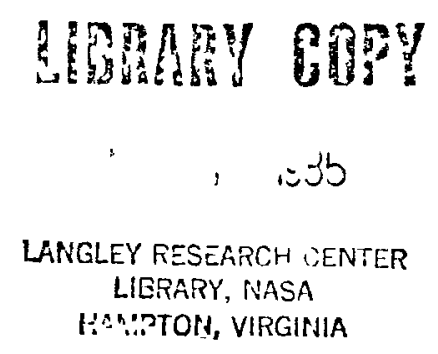

Prepared for the

Twenty-third Aerospace Sciences Meeting sponsored by the American Institute of Aeronautics and Astronautics Reno, Nevada, January 14-17, 1985

\section{N/SN}


THE UH-1H HELICOPTER ICING FLIGHT TEST PROGRAM AN OVERVIEW

Robert J. Shaw and G. Paul Richter

National Aeronautics and Space Administration

Lewis Research Center

Cleveland, Ohro 44135

\section{Abstract}

An overview is given of the elements of an ongoing joint NASA/Army program to study the effects of ice accretion on unprotected helicopter rotor aerodynamic performance. This program integrates flight testing, wind tunnel testing, and analytical modeling. Results are discussed for helicopter flight testing in the Canadian NRC hover spray rig facility to measure rotor aero performance degradation and document rotor ice accretion characteristics. The results of dry wind tunnel testing of airfoil sections with artificial ice accretions and predictions of rotor performance degradation using avallable rotor performance codes and the wind tunnel data are presented. An alternative approach to conducting future helicopter icing flight programs is discussed.

\section{Nomenclature}

A

$c_{p_{1}}, c_{p_{u}}$

C

LWC

$P_{S}$

$P_{\infty}$

Q

$R$

$r$

shp

$x$

a

$(\Delta C$ do $)$ avg

$\Delta C_{p}$

$\triangle H P_{\text {avg }}$

$\Delta H P_{\text {req }}$

$\sigma$

$\rho_{\infty}$

2 main rotor area $\left(168.11 \mathrm{~m}^{2}\right)$

alrfoll lower, upper surface pressure coefficients where $C_{p}=\left(P_{s}-P_{\infty}\right) / Q_{\infty}$

rotor airfoll chord $(0.533 \mathrm{~m})$

icing cloud liquid water content

local static pressure

free stream static pressure

free stream dynamic pressure

rotor radius $(7.315 \mathrm{~m})$

radial coordinate

rotor shaft horsepower

airfoil axial coordinate

angle-of-attack

average increase in rotor section drag coefficient

change in rotor power coefficient where $C_{p}=($ Power $) / \rho_{\infty} A(\Omega R)^{3}$

average increase in horsepower required change in rotor horsepower required

density ratio

ambrent density

rotor rotational speed

\section{Introduction}

Some of the most difficult aircraft icing problems are those associated with the helicopter. In recent years, an increased emphasis has been placed on the need for both military and civilian helicopters to be able to fly into forecast icing conditions. To date only one civilian rotorcraft, the French Super Puma, has received icing certification from the FAA. The rotor of the helicopter presents some of the most complex icing problems. As Ref. 1 points out.

"Rotor icing and ice protection techniques present a unique set of problems (aerodynamic, dynamic, thermodynamic) that are not easily solvable through fixed-wing ice protection technology. Ice formations on the rotor cause degradation in helicopter performance, the degree of performance change depending upon specific rotor characteristics (airfoil profile, blade loading, Mach number distribution, catch efficiency, blade flexibility, rotor/airframe reaction, control loads, etc.)"

A key step in developing the required technology base needed for solving helicopter rotor icing problems is the acquisition of flight data for both simuiated and natural icing conditions for unprotected rotors operating in hover and forward flight. This data base should include detailed measurements of the rotor ice accretion shape characteristics and the resultant rotor performance degradation levels (e.g., increased levels of required horsepower to sustain firght). This data base can then be used to validate analytical techniques being developed to predict rotor ice accretion and resultant aerodynamic performance degradation, 2 and to evaluate the usefulness of studying rotor icing characteristics using exper mental test rigs such as full scale oscillating rigs and model rotors in icing wind tunnels. Also, the data base can be used to determine the effects of forward flight on ice accretion characteristics.

The validation of simulation approaches such as those described above should reduce the amount of natural icing flight testing required for future helicopter icing certification programs. It is well recognized that natural icing flight testing is a very expensive, uncontrolled approach to evaluating aircraft performance in icing. This is particularly true for the helicopter which has a 1 imited range of operation. Often many seasons of flight testing are required to acquire an adequate data base. 3

With these thoughts in mind, NASA and the U.S. Army have undertaken a joint program called the Helicopter Icing Flight Test Program (or HIFT Program) to begin to acquire the needed rotor icing data. Complementary efforts have also been started by NASA to evaluate the analytical and ground-based experimental simulation approaches. This paper will present an overview of the current program 
status and indicate possible future efforts. The HIFT Program required coordinated efforts from many organizations. Table 1 shows the responsibilities of the various organizations involved in the program.

The combined efforts of many individuals from the U.S. Army, Air Force Arnold Engineering Development Center, the Ohio State University, Hovey and Associates, and Bell Helicopter Textron made the HIFT program possible.

\section{HIFT Program Objectives and Organization}

The phase one efforts of the HIFT program involved helicopter icing in the hover mode. Specifically, the major elements of the program are shown in Fig. 1 along with an indication of how the elements relate to one another. The following paragraphs will discuss some important detalls associated with each of the elements.

\section{Helicopter Icing Flight Testing}

The hover icing tests were conducted in the Canadian National Research Council's 0ttawa Spray Rig located adjacent to the Uplands airport. This outdoor facility, the only hover icing facility currently available for flight tests, is fully discussed in Ref. 4. The spray $r i g$ is a framework (Fig. 2) which measures $75 \mathrm{ft}$ wide by $15 \mathrm{ft}$ high and $1 \mathrm{~s}$ attached to a $59 \mathrm{ft}$ mast. A total of 156 steam atomizing nozzles are located on this framework, and they are spaced $3 \mathrm{ft}$ apart on 30 vertical bars. The icing cloud is created by using pressurized steam to atomize water into a spray with the desired water droplet sizes. Icing cloud liquid water content (LWC) is primarily governed by water flow rate and wind speed while the droplet size is primarily a function of the steam pressure level. The framework can be rotated in order to align it perpendicular to the prevailing wind. The spray rig requires a wind velocity of at least 6 knots to carry the cloud over the helicopter.

The helicopter used for the HIFT Program was a Bell Helicopter Textron UH-1H "Huey" provided and operated by the U.S. Army Aviation Englneering Flight Activity (USAAEFA). The UH-1H is a thirteen-place, single engine configuration which has a single, two-bladed teetering main rotor. The maximum gross weight of the UH-1H is $9500 \mathrm{lb}$. The helicopter is powered by a Lycoming T53 engine, and the main rotor transmission is limited to 1100 shp for continuous operation. Figure 2 shows the UH-1H helicopter in the Ottawa spray rig facility while Fig. 3 shows a schematic of the UH-1H with important details noted. The required instrumentation was provided by the Army and installed by Army personnel (USAAEFA) with the exception of the main rotor blade load instrumentation which was installed by Bell Helicopter Textron personnel. A complete listing of the helicopter instrumentation 15 contained in Ref. 5.

\section{Ice Shape Documentation}

Three different approaches were employed to document rotor ice accretion shapes and an evaluation was made of the relative merits of each. The three approaches employed were, (1) stereo photography, (2) silicone molding, and (3) crosssectional tracings. Ice shape documentation occurred after the helicopter was flown in the spray $\mathrm{r}, \mathrm{g}$ and then landed, with the lced rotor brought to rest.

The ice accretion documentation phase was conducted in a special climate controlled work station shown in Fig. 4 . The work station, a modified airline galley truck with inside dimensions of 20 by 7 by $4 \mathrm{ft}$, was backed up to the helicopter so that one of the main rotor blades could be positioned within the truck. The truck interior was then sealed from the outside by using the truck door and a tarp and the interior temperature brought up to about $-5{ }^{\circ} \mathrm{C}$ using space heaters. The documentation station was kept at subfreezing temperatures to ensure that no ice melted during the time the liquid molding material required to harden.

The stereophotographic technique was developed by Arvin/Calspan Field Services, Inc. for the Arnold Engineering Development Center (AEDC) of the Air Force Systems Command. Wide angle stereo pairs of photographs of the rotor leading edge ice accretions were taken using two $70 \mathrm{~mm}$ Hasselblad cameras equipped with $50 \mathrm{~mm}$ lenses. The stereo pair photographs were taken over the span of the iced rotor blade and were centered on $1 \mathrm{ft}-\mathrm{w}$ ide segments every $2 \mathrm{ft}$ starting $5 \mathrm{ft}$ from the hub. Figure 5 shows the overall stereophotography setup employed. Three sets of photographs were taken at each location with the two cameras located approximately, (1) $1 \mathrm{ft}$ above the rotor chord plane, (2) on the chord plane, and (3) approximately $\mathrm{i}$ ft below the rotor chord plane. Post flight analysis of the stereo pair photographs in order to determine local two-dimensional ice accretion shapes was performed at AEDC using an avallable stereo-compller. Reference 6 gives a more detailed discussion of the stereo photography set up and data reduction procedures employed.

The silicone molding technique involved placing $1 \mathrm{ft}$ wide plywood mold boxes around the iced UH-1H rotor every $2 \mathrm{ft}$ along the span. The mold boxes were designed and fabricated to ensure a tight $f_{1} t$ around the airfoil contour and to allow for molding of an ice accretion as much as 2 in ahead of the airfoll and 6 in aft of the leading edge. Figure 6 shows the details of the mold box construction. The material used to form the molds was a mixture of Dow Corning silicone rubber (RTV 3110) mixed with thinner and catalyst compounds. The choice of this mixture was based upon the results of studies conducted at NASA Lewis and information from previous research efforts avallable in the literature. Prior to use, the molding mixture was degassed to remove unwanted air bubbles using a vacuum pump arrangement. The degassing process took about $15 \mathrm{~min}$ to complete.

The molding mixture was made thin (i.e., the consistency of cake batter) so that when it was poured into the mold box cavities, it would flow freely around the ice in order to document the small scale characteristics of the ice accretion. It generally took about 2 to $3 \mathrm{hr}$ (at temperatures below freezing) for the silicone mixture to harden to a sufficient degree that the mold boxes could be removed from the rotor blade. Figure 7 shows the $\mathrm{UH}-1 \mathrm{H}$ rotor blade with mold boxes attached. A more complete discussion of the molding technique is given in Ref. 7 . 
The tracing technique involved making chordwise cuts of the $1 c$ accretion every $2 \mathrm{ft}$ of the rotor span using a hot wire electric knife. A cardboard template was then inserted into the cut, and a pencil tracing was made of the leading edge ice accretion.

\section{Dry Transonic Wind Tunnel Tests}

Selected silicone molds were used to fabricate artificial leading edge ice accretion shapes which were attached to full scale rotor sections. The sections were tested in a dry transonic wind tunnel to measure local airforl section performance degradations due to the ice accretions. Figure 8 shows a typical casting fabricated from epoxy and affixed to a UH-1H rotor section. Surface static pressure taps were installed over the forward 35 percent chord of the models to determine the effects of the ice accretions on airforl boundary layer development.

The wind tunnel tests were conducted in the Fluidyne Engineering Corporation (Minneapolis, Minnesota) 66 by 66 in Transonic Wind Tunnel Facility. This facility is an atmospheric total pressure wind tunnel with a slotted wall test section and is driven by a set of ejectors aft of the test section. Model drag levels were measured with a wake rake. A more complete discussion of the Facility is given in Ref. 8.

\section{Analytical Predictions of Rotor Performance}

As already indicated, the 0ttawa Spray Rig requires a wind speed of at least 6 knots to carry the icing cloud out over the helicopter. Thus, the helicopter flight environment is not truly hover and this small but finite forward velocity must be accounted for in the analysis of the rotor performance. To perform this analysis, two different approaches were tried. The first approach was a conventional forward flight analysis methodology developed by Bell Helicopter Textron and called ARAM 45.9 This analysis is based on blade element momentum theory and includes a capability for treating unsteady aerodynamic, compressibility, and finite blade effects.

The second approach was an extrapolation technique also developed at Bell which corrects the predicted hover performance power levels by making momentum theory corrections to predictions of both profile and induced power levels. This approximate approach is discussed in detail in Ref. 10.

The next section will discuss some of the results for each of the major elements of the phase one program.

\section{Results and Discussion}

\section{Hover Flight Testing}

As already indicated, the two major objectives of the flight testing were, (1) to measure rotor performance degradation due to $1 \mathrm{cing}$, and (2) to document the rotor ice accretions. Pretest discussions between NASA, Army, and Bell Helicopter Textron personnel resulted in a decision to attempt to fly a series of tethered hover flights before and after accreting ice in the spray rig. However, initial test flights revealed that a large portion of the ice was shed due to rotor blade flexing when the second set of tethered hover points was acquired. The test technique finally adopted was as follows:

(1) Determine rotor baseline profile power levels required by conducting a flat pitch speed runup with the aircraft on the ground

(2) Fly a baseline out-of-ground effect (OGE) free hover point

(3) Enter the spray rig cloud, accrete ice, and exit the cloud

(4) Fly a free hover point to determine hover performance degradation

(5) Land the aircraft and conduct a second flat pitch speed runup

(6) Bring the rotor to rest, move the ice shape documentation station into place, and document the rotor ice accretion characteristics

This test technique was judged to be successful in that ice shedding was minımized.

A total of ten research flights were conducted during the flight test program which lasted from mid January to mid March (1983). Unfortunateiy, unseasonably warm weather occurred in the ottawa area during this period, preventing any more flights from being attempted. For five of the ten flights, the ice accretion was retained on the rotor blades. A summary of these five flights (designated as flights A through $E$ ) is given in Table 2. The liquid water content figures shown were determined from the NRC calibration of the spray $\mathrm{rig}^{4}$ which requires an estimate to be made of the wind gust conditions ("low, medium, or high"). The estimates for the various flights are also given in the table. The volume median droplet diameter for all test conditions was $30 \mu$ as determined from the avallable NRC calibration. It should be noted that the main rotor torque instrumentation was inoperative for flights $C$ and $D$. Thus, "complete" data sets (1.e., ice accretion and rotor performance degradation levels) were acquired for flights $A, B$, and $E$. It is these three flights which the remainder of the paper will focus on. However, tracings for flight $D$ are presented in Ref. 5 and molds and stereo photographs were acquired for flight $C$.

The flat pitch speed runup procedure was employed to acquire data which would, (1) verify that the main rotor performance instrumentation was functioning properly, and (2) allow an estimation to be made of the mean profile drag coefficient for the iced rotor while operating at an approximate zero lift condition.

Profile power is an indication of the power required to pull the rotor through the air and varies linearly with the cube of the angular velocity. Figure 9 shows the profile power curves for the baseline (clean rotor) measurements and the corresponding curves for the iced rotor for flights $A, B$, and $E$. The data shown in Fig. 9 were corrected for compressibility using a standard Prandtl-Glauert correction. Average rotor profile drag coefficients $\left(\mathrm{Cd}_{0}\right)$ avg were calculated. The results summarized in lable 3 indicate flight $E$ had the highest $\left(\mathrm{Cd}_{0}\right)$ avg value $(0.0110)$ for the three flights. Tabie 3 also indicates the average increases in profile rotor horsepower ranged from 60 for flight $E$ to 25 for flight $A$. 
Table 4 summarizes the hover performance measurements made for flights $A, B$, and $E$. Also noted in the table are the maximum ice thicknesses measured at the rotor mid span station and the percent of span of the rotor over which ice had accreted. (That is for flight E, ice was accreted over the first 92 percent of the span.) As the table indicates, the rotor hover performance degradation was the greatest for flight $A(+101$ shp expressed in equivalent standard day conditions). This is just opposite to the results of the profile power measurements (Table 3 ) where flight $A$ showed the smallest average profile power coefficient for the three flights.

It is hard to definitely explain this apparent anomaly. However, the flight log for flight $A$ indicates that some ice over the rotor span was shed during landing. Thus, the rotor span coverage noted on Table 4 corresponds to the extent of ice remaining after the second flat pitch runup was completed, and thus a direct comparison of performance losses for flat pitch runup and for hover for the three flights is not justified. Previous analytical studies of rotor aerodynamic performance degradation due to icingll have shown that the rotor is most sensitive to ice accretions over the outermost portion of the span, and the loss of outer span ice for flight A may explain why the horsepower increase for flat pitch runup was so low. The instrumentation appeared to be working properly for this flight as indicated by the agreement in clean rotor profile power levels measured for the three flights (Fig. 9).

The avallable rotor ice accretion tracings for the three flights are shown in Fig. 10 for various radial locations. As the figure indicates, only three tracings were taken for flight $A$, those being at $r / R=0.31,0.40$, and 0.49 . However, it has already been indicated that ice coverage was noted out to $r / R=0.75$ but unfortunately no ice shape detalls were preserved for this critical outer span region. The three tracings for flight A show relatively rounded ice accretions which look something like rime ice shapes which characteristically result in smaller airfoll performance losses than do glaze ice accretions.

The tracings avallable from flight $E$ show less streamlined characteristics over the inner span $(r / R=0.56)$ with a transition to smaller, more rounded shapes over the outer span region. In particular, the ice tracing at $r / R=0.81$ is very small and rounded.

On comparison of these three sets of ice shape tracings, one might conclude that while the inner span ice accretion shapes for flight $E$ appeared to be worse than those for flight $A$, the outer span ice accretion characteristics for flight $A$ (which were not documented) might have been more disruptive to the local flow over the rotor than were those for flight E. Clearly, more outer span documentation for the two flights should have been acquired.

This possible anomaly with the hover ice accretion/aerodynamic performance degradation data for flights $A$ and $E$ points out some inherent problems with the basic test procedure which had to be employed. As already indicated, the desire was to measure a thrust-power curve for the UH-1H with the rotor ice accretions. However, the flexing of the rotor blades during the data acquisition resulted in a large amount of ice shedding and thus the data was rendered useless. Thus, only one point on the thrust-power curve could be obtained prior to landing the alrcraft and completing the flat pitch runup. This is obviously an undesirable situation in that helicopter filght test data and in particular that for the UH-1H characteristically exhibit some scatter, and it is desirable to acquire large quantities of data in order to determine a statistically significant curve. It is possible that some of the discrepancy in increased power requirements for flights $A$ and $E$ could be explained by data scatter.

Also, it should be noted that the ottawa spray rig requires a minimum wind speed of about 6 knots to carry the icing cloud out to the rotor. Thus, the helicopter is not operating in a true hover mode either when the ice is being accreted or when the performance measurements are being made. The original test plan for the flight testing had specified that a precision low airspeed sensing system be installed in the UH-1H and be used as an airspeed indicator. However, such a system was not avallable and as a result, a cup anemometer located on top of the spray rig had to be used. This anemometer system would be expected to be somewhat less accurate than the low airspeed sensing system. The low forward flight velocity regime is characteristically a very sensitive one for a helicopter as the aircraft is very sensitive to gusts which can cause significant changes in power required. At such low velocities, the induced power is sensitive to wake position which can significantly vary with small changes in forward velocity. In order to assess this sensitivity, analysis was carried out at Bell Helicopter Textron using a forward flight rotor performance prediction code to determine change in power required for the $\mathrm{UH}-1 \mathrm{H}$ as a function of forward velocity (information received in private communication from L.F. Berkowitz of Bell Helicopter Textron). The results are shown in Fig. 11 where the horsepower required increases for flights $A, B$, and $E$ are compared to the decrease in horsepower required when the forward velocity was increased from 5 to 15 knots. As the figure clearly indicates, the magnitudes of the changes in horsepower required are the same for the icing flights as that due to a change in forward velocity. This figure indicates the forward velocity must be known very accurately when measuring performance losses due to icing at very low forward flight speeds.

More recent $h i g h$ speed wind tunnel tests of scale rotor airfoll sections 12 have indicated that appreciable erosion/sublimation effects can occur when the iced airfoil is exposed to a high speed airflow for several minutes. In particular, that study showed that the section drag coefficients could be reduced by as much as 40 percent below the level measured immediately after the ice accreted if the iced airfoil was exposed to a high Mach number air flow for several minutes. The performance measurement technique employed during the HIFT phase one flight testing required several minutes to complete the rotor hover performance measurement, land the aircraft, complete the flat pitch power runup, and bring the rotor to rest to document the ice accretion characteristics. Since the outer regions of the UH-1H rotor are subjected to relatively high Mach number environments 
$\left(M_{t}\right.$ p $\approx 0.7$ to 0.8$)$, ice accretion erosion/sublimation could have occurred to significantly affect the rotor performance measurements made. However, the magnitude of this effect cannot be quantified at the present time.

With the above thoughts in mind, some comments regarding possible approaches to follow in future tests seem to be in order. It would seem to be very important to have some in flight photographic techniques to document the rotor ice accretion characteristics. If a hub mounted camera system such as that developed by the British ${ }^{3}$ or the rotor head video camera being developed by the Army were available, a determination of span coverage of the ice and any shedding which occurred could be determined. However, these systems could not provide any quantitative details of the ice accretion. A proposed system which might yield such information would be a stereo photography system such as that proposed by NASA and AEDC personne1. 13 This approach is attractive in that conceptually it would be possible to document ice accretion characteristics at the same time the performance degradation measurements were being made. However, it must be acknowledged that the stereo system discussed in Ref. $13 \mathrm{stil1}$ requires significant development.

Also, an alternate and possibly more attractive experimental approach $c$ an be suggested. The helicopter rotor would be allowed to accrete ice for the desired length of time and then the aircraft would be immediately landed, taking care not to shed any ice by any abrupt changes in collective pitch, etc. The ice accretion along the rotor would immediately be documented using one or more of the techniques discussed above. Bypassing the acquisition of any iced rotor performance data would minimize the ice accretion exposure to the high speed erosion environment and thus preserve the "best" ice accretion definition. After the icing flight testing is completed, the ice shape documentation can be used to fabricate artificial ice accretions which would be affixed to the leading edge. Of course these artificial ice accretions should have the proper mass characteristics to accurately simulate the effects of real ice accretions on rotors. Conventional dry air flight test techniques could then be employed with the artificially iced rotor to accurately determine the performance degradation due to icing. Of course, this approach is predicated on the assumption that it is possible to accurately model the key features of natural ice accretions so that the aerodynamic flowfield will be adequately duplicated. Research to verify this assumption is currently underway. 14

This method does suffer from the drawback that additional flight testing is required. However, it is felt that the additional expense associated with this testing can be justified on the grounds that the quality (and hence believability) of the performance degradation measurements will be greatly improved.

\section{Ice Shape Documentation}

On site inspection of the rotor ice accretions indicated that a considerable amount of local three dimensional detall existed ${ }^{14}$ as revealed in Fig. 12. The tracing technique and to a certain extent the stereo photography technique capture the two dimensional nature of the ice accretion at the spanwise station of interest. The tracing technique requires the least time and effort to employ, but it cannot be used to document any of the detalls of the surface roughness characteristics of the ice accretion. However, as Ref. 6 points out, the stereo photography approach does show promise for being able to document the roughness characteristics, but additional research and development is required.

The silicone molding technique appears to make almost exact reproductions of the ice accretion characteristics, including the most minute three dimensional details. Figure 13 shows two views of a mold obtained during the program. While the photographs do give some appreciation for the detail preserved, a personal inspection is required to truly appreciate the detalls. However, it should be pointed out that the silicone mold does require a significant amount of time to harden (approximately 2 to $3 \mathrm{hr}$ ), and thus the amount of data which can be acquired is limited.

Figure 14 compares the ice shape details avallable from the three methods. The profiles are shown for $r / R \approx 0.46$ for flight $E$. To reduce the silicone mold to a two dimensional cross section, a photograph was taken of the edge of the appropriate mold. A comparison of the three tracings indicates that some differences in ice shape characteristics did exist between the three methods; however, these variations are judged to be no greater than those that would be obtained by using any one method and taking several closely spaced "slices." That 15, the ice accretion exhibited some locally three dimensional detalls as already discussed (Fig. 12).

\section{Dry Wind Tunnel Test Program}

Flight $E$ was chosen for follow on dry wind tunnel tests of rotor sections with artificial leading edge ice accretions and then computer analyses of rotor performance degradation. This choice was dictated primarily by the relatively large degradation in hover performance measured as well as the existence of rotor ice accretion out to about 92 percent span.

Based upon rotor performance analyses conducted by Bell Helicopter Textron personnel (information received in private communication from L.F. Berkowitz of Bell Helicopter Textron) and avarlable rotor ice accretion documentation, four stations were chosen for wind tunnel testing. The four stations chosen were at nondimensional radial locations ( $r / R)$ of $0.44,0.60,0.77$, and 0.94 . Since ice accretion occurred to $r / R$ of about 0.92 for flight $E$, only three "iced" airforl models were tested in addition to a clean airforl model which served as a baseline reference. The conditions chosen from wind tunnel testing were determined from the rotor analysis performed by Bell Helicopter Textron. Since the rotor ice accretion and performance data were acquired in a near hover mode (1.e., a finite forward wind speed existed), a forward flight analysis code had to be used and thus the local Mach number and angle-ofattack conditions for each radial station did vary with azimuthal position of the rotor blade. Figure 15 shows the two boundary curves for rotor section operation conditions, the lower curve corresponding to flat pitch runup conditions and the upper curve corresponding to the near hover 
performance conditions. The figure also shows the critical flow boundary for the NACA 0012 airforl, and it $c$ an be seen that supercritical conditions would be expected for the $r / R=0.77$ and 0.94 stations. Wind tunnel test points for each model were chosen to be within the two boundaries and along the appropriate operating line shown in the figure so as to adequately document any Mach number or angle-of-attack effects on section drag levels.

The wind tunnel test models were fabricated using the appropriate flight $E$ silicone molds and full scale sections of UH-1H rotor blades supplied by the U.S. Army. Replicas of the leading edge ice accretions were cast to the rotor section models using epoxy as the casting material. To cover the span of the wind tunnel test model, the mold was used to make repetitive castings starting at the midspan. The models were instrumented with surface static pressures over the first 35 percent chord to determine boundary layer growth characteristics. Figure 16 shows one of the models installed in the Fluldyne Transonic Wind Tunnel.

The section drag coefficient levels measured for the three test models corresponding to $r / R=$ $0.44,0.60$, and 0.77 are shown in Fig. 17 as a function of angle-of-attack which has been corrected for tunnel downwash interference. The clean airfoll reference drag levels are also shown. It should be noted that the Mach number was varied as a function of angle-of-attack for those models corresponding to the $r / R=0.60$ and 0.77 iced airfolls so as to choose test points which were close to the respective operating lines shown in Fig. 15. The experimental Mach number variation was 0.42 to 0.54 for the $r / R=0.60$ accretion model and 0.53 to 0.69 for the $r / R=0.77$ accre$\mathrm{t}$ ion model. For the most inboard model $(r / R=$ 0.44 ), the Mach number was taken to be constant $(0.36)$. Also for reference, the figures show reference ice shape tracings which are the same as some of those shown in Fig. 10.

As the figure indicates, the largest drag levels were measured for the inboard ice accretion $(r / R=044)$ with a maximum drag coefficient of 0.080 being recorded for a corrected angle-ofattack of $8.12^{\circ}$. The rapidly increasing drag coefficient level with increasing angle-of-attack suggests a large scale, upper surface flow separation had occurred. Figure 18 shows leading edge surface pressure coefficient variations both for the iced airfoll and the reference clean airfoll for an angle-of-attack of $5.9^{\circ}$. These profiles shown in differential form indicate a difference in the surface pressure characteristics for the iced airfoil occurred from $x / c=0.05$ to 0.35 . This reduction in level of pressure coefficient differential is indicative of a reduction in lift for the airfoll, and the nature of the iced airfoll curve (a plateau existing from $x / c=0.2$ to 0.3 ) suggests the presence of a separation-reattachment zone. The presence of a localized separationreattachment zone has been observed for other iced airfoils in other experimental programs. While the pressure differential plot of Fig. 18 suggests only a small change in $11 \mathrm{ft}$ occurred at a $5.9^{\circ}$ angle-ofattack, the rapid increase in drag at the higher angles shown in $\mathrm{Fig} .17$ for the $r / R=0.44$ ice accretion suggest the separation-reattachment zone grew to a much greater size. For these higher angle-of-attack conditions, the effect of the leading edge ice accretion on the $11 \mathrm{ft}$ (and also pitching moment) characteristics would be expected to be more significant

The drag coefficient curves for the other two ice accretion shapes $(r / R=0.60$ and 0.77$)$ show smaller increases relative to the clean airfoil baseline curves. This is to be expected as the corresponding ice accretion shapes are somewhat more "aerodynamic" in cross section as Fig. 17 indicates.

Even though the test matrix was very limited for each of the iced airforl models (primarily due to program funding constraints), some understanding of the effect of the ice accretions on the UH-1H airfoll performance was determined. However to gain a more complete understanding of the airforl performance many more wind tunnel test conditions would have to be run. These conditions should include Mach number variations at constant angleof-attack and angle-of-attack variations at constant Mach number (for both low and high Mach numbers).

\section{Rotor Performance Degradation Analysis}

As already indicated, two analysis methods were used to predict the $\mathrm{UH}-1 \mathrm{H}$ rotor performance degradation due to 1 cing - a conventional forward flight analysis code and an extrapolation technique based on a hover analysis. Both analysis codes required that an airfoil data table be prepared which related iced airfoil lift and drag coefficients as a function of Mach number and angle-of-attack. Since airfoil section surface pressure profiles were not measured, the iced airfoll lift coefficient had to be assumed to be equal to the corresponding clean airforl lift coefficient. As already indicated in the previous section, this does not appear to be a bad assumption at least for moderate angles-of-attack. Thus, only a drag coefficient specification had to be provided.

Both the hover and forward flight analysis codes required local section data for 21 radial locations for each $15^{\circ}$ azimuthal position. (of course for the hover analysis, there is no azimuthal dependence.) Primarily due to program funding limitations, it was possible to conduct wind tunnel tests for only three different radial locations $(r / R=0.44,0.60$, and 0.77 ). Thus it was necessary to provide entries in the data table for the other radial locations. In the absence of any additional information, it was decided to use the small amount of data avallable (Fig. 17) to extrapolate/interpolate to the other conditions required. Obviously this is a gross approximation as it implicity ignores the variation in ice shape along the span of the rotor and the effect of changing ice shape on aerodynamic performance levels. However, it was felt that this was the best approximation which could be made.

The results of the two analysis predictions performed by Bell Helicopter Textron personnel compared to the flight test measurement for flight $E$ are shown in Fig. 19. The results are judged to be surprisingly good. The flight test results indicated an increase in required horsepower of 96 while the forward flight analysis predicted 100 and the hover extrapolation method predicted 88 . Of course, these results may be somewhat fortuitous in view of the several concerns already mentioned 
with regard to the normal scatter of the flight test data, limited amount of avallable flight test and wind tunnel data, and sensitivity of helicopter performance to small changes in forward velocity. Nevertheless, these results do appear to somewhat justify the correctness of the method and suggest the need for continued research is warranted.

\section{Concluding Remarks}

While the results of the phase one HIFT efforts were 11 mited in terms of amount of flight test and supporting wind tunnel data which could be acquired, the program was judged to be successful. In particular, the agreement between predicted and measured rotor performance degradation was surprisingly good. Also, experimental techniques were developed which allowed rotor ice accretions to be documented in great detall without any apparent loss of any ice due to blade flexing during landing.

These techniques were employed to conduct a phase two of the HIFT program which involved flight of the UH-1H helicopter behind the Army's Hel1copter Icing Spray System (HISS tanker) to accrete ice in forward flight conditions, measure rotor performance degradation, and then land the hel1copter to document rotor ice shapes using the silicone molding technique. The results of these forward flight icing tests which were conducted near Duluth, Minnesota during the winter of 1983-84 are given in Ref. 16. Analysis of this data is currently underway. Follow on wind tunnel tests and analytical predictions are also planned.

In spite of the limited data available from the HIFT program some tentative conclusions $c$ an be drawn which should be considered for future helicopter icing flight tests being planned.

1. Both the phase one and two programs have shown it is possible to accrete ice on the rotor blades of an unprotected helicopter either in hover or in forward flight and then land the aircraft without shedding any significant amounts of ice.

2. However, it does not appear to be possible to make a sufficient number of inflight performance measurements with an iced rotor to get a meaningful performance curve. Shedding a significant amount of ice from the rotor usually occurs during these performance measurements. The number of points which may be acquired are so few that the inherent data scatter may mask icing related trends.

3. The time required to make the few inflight performance measurements which can be acquired is long enough that concern about erosion of the ice shapes especially near the high Mach number tip region exists. This ice shape erosion has been seen in at least one previous high speed icing wind tunnel test of scale rotor airfoil sections.

4. The silicone molding approach appears to be a desirable documentation approach to take in that the most minute three dimensional details of the rotor ice accretion can be preserved, and highly accurate three dimensional castings of the rotor ice accretion can be fabricated from these molds.

5. In view of the concerns suggested in (1) through (3) and with the avallability of the silicone molding technique, it is suggested that future helicopter icing flight tests be limited to documentation of rotor ice accretion characteristics only, whether for hover or forward flight conditions. That 1s, no rotor performance degradation data be taken, rather the ice accretion molds acquired would be used to fabricate artificial leading edge ice accretions and a second flight test be conducted with these artificial ice shapes of proper mass characteristics affixed to the leading edge. While this admittedly increases the amount of helicopter flight test time required, it is felt that with the artificial ice accretions a significant number of performance points could be acquired which would allow a more accurate determination to be made of rotor degradation due to 1 cing. It is necessary to have a high level of confidence in the flight test data before the rotor 1 cing analysis methodologies under development can be rigorously evaluated. A "one point" evaluation such as described in this paper is certainily not sufficient to validate the analysis methodologies.

6. Additional research needs to be conducted to validate the assumption that artificial ice accretions affixed to the leading edge of rotor airfoll sections will cause the same changes in airfoll aerodynamic performance as will real ice accretions. The amount of surface detall required when fabricating the artificial ice shapes must also be determined.

\section{References}

1. Peterson, A.A., Dadone, L., and Bevan, D. Rotorcraft Aviation Icing Research Requirements Research Review and Recommendations. (D210-1162-1, Boeing Vertol Co., NASA Contract NAS3-22384) NASA CR-165344, May 1981.

2. Shaw, Robert J. Progress Toward the Development of an Aircraft Icing Analysis Capability. NASA TM-83562, 1984.

3. Dunford, Philip J. New Techniques for Optimization and Certification of Helicopters in Icing Conditions. Presented at the AHS National Specialist's Meeting on Helicopter Testing Technology. (Williamsburg, VA) Oct. 29 - Nov. 1, 1984.

4. Bailey, D.L. Description of the Spray Rig Used to Study Icing on Helicopters in Flight. Second Revised Edition. Aeronautical Report LR-186A. National Research Council of Canada, Sept. 1960.

5. Abbott, William $Y$., et al Evaluation of UH-1H Hover Performance Degradation Caused by Rotor Icing. USAAEFA Report 82-12, Aug. 1983. (AD-A141252)

6. Palko, R.L., and Cassady, P.L. Photogrammetric Analysis of Ice Burldup on a U.S. Army UH-1H Helicopter Main Rotor in Hover Flight. AEDC-TR-83-43, Oct. 1983. (AD-B077844L)

7. Lee, John D., Harding, Rorry, and Palko, Richard L.* Documentation of Ice Shapes on the Main Rotor of a UH-1H Helicopter in Hover. NASA CR-168332, Jan. 1984. 
8. Berger, Jack $H$, and McDonald, Timothy J.' Wind Tunnel Tests of Airforl' Shapes Altered by Icing and Airfoil Shapes With Deicer Boots. FlurDyne Report 1402, FluiDyne Engineering Corp., Jan. 1984.

9. Harrıs, Franklin D., et al: Helicopter Performance Methodology at Bell Helicopter Textron. American Helicopter Society, Annual National Forum, 35th, Proceedings, American Hel icopter Society, May 1979, pp. 79-2-1 to 79-2-47.

10. Harris, F.D.: Model 222 Performance Data Base for Hover and Low Speed Flight. BHTI 10M81, Bell Helicopter, Apr. 10, 1978.

11. Korkan, K.D., Shaw, R.J.; and Dadone, L.: Performance Degradation of Helicopter Rotor Systems in Forward Flight Due to Rime Ice Accretion. AIAA 83-0029, Jan. 1983.
12. Flemming, R.J., and Lednicer, D.A.: Experimental Investigation of Ice Accretion on Rotorcraft Airfolls at High Speeds. AIAA-84-0183, Jan. 1984.

13. Palko, Richard L., et al Initial Feasibility Ground Test of a Proposed Photogrammetric System for Measuring the Shapes of Ice Accretions on Helicopter Rotor Blades During Forward Flight. AEDC TR-84-10, Aug. 1984.

14. Lee, J.D.: Aerodynamic Evaluation of a Hel1copter Rotor Blade with Ice Accretion in Hover. AIAA 84-0608, Mar. 1984.

16. Abbott, W.Y., et al: Evaluation of UH-1H Level Flight Performance Degradation Caused by Rotor Icing. USAAEFA Report 83-23, July 1984. 
TABLE 1. - ORGANIZATIONAL CHART FOR THE HIFT PROGRAM (PHASE ONE)

\begin{tabular}{|c|c|}
\hline Group & Responsibilities \\
\hline $\begin{array}{l}\text { 1. NASA Lewis } \\
\text { 2. Army Aviation Engineering Flight } \\
\text { Activity (AAEFA) } \\
\text { 3. Army Applied Technology Laboratory (ATL) } \\
\text { 4. Dept. of Aeronautical and Astronautical } \\
\text { Engineering, 0hio State University } \\
\text { (Prof. J.D. Lee) } \\
\text { 5. Canadian National Research Council } \\
\text { 6. Hovey and Associates (Ottawa, Canada) } \\
\text { 7. Calspan (AEDC) } \\
\text { 8. Fluidyne Engineering Corporation } \\
\text { 9. Bell Helicopter Textron }\end{array}$ & $\begin{array}{l}\text { Overall technical guidance, program coordination, } \\
\text { partial funding } \\
\text { Instrumented Helicopter, flight test crew, performance } \\
\text { measurements } \\
\text { Partial funding } \\
\text { Ice shape documentation coordination, dry wind tunnel } \\
\text { testing coordination } \\
\text { Spray rig operation } \\
\text { Silicone molding, tracing } \\
\text { Stereoscopic photography } \\
\text { Dry wind tunnel tests } \\
\text { Rotor icing performance evaluation (analysis and } \\
\text { experimental) }\end{array}$ \\
\hline
\end{tabular}

TABLE 2. - SUMMARY OF HOVER ICING FLIGHTS

\begin{tabular}{|c|c|c|c|c|c|}
\hline \multirow{2}{*}{$\begin{array}{l}\text { Flight } \\
\text { number }\end{array}$} & \multicolumn{2}{|c|}{ Wind } & \multirow{2}{*}{$\begin{array}{l}\mathrm{LWC}, 3 \\
\mathrm{gm} / \mathrm{m}^{3}\end{array}$} & \multirow{2}{*}{$\begin{array}{c}\text { Ambient } \\
\text { temperature, } \\
{ }_{C}\end{array}$} & \multirow{2}{*}{$\begin{array}{c}\text { Time in } \\
\text { cloud, } \\
\text { min }\end{array}$} \\
\hline & $\begin{array}{c}\text { Speed, } \\
\text { kn }\end{array}$ & Gustiness & & & \\
\hline $\begin{array}{l}\text { A } \\
B \\
C \\
D \\
E\end{array}$ & $\begin{array}{r}7 \\
10 \\
6 \\
4 \\
9\end{array}$ & $\begin{array}{l}\text { Medium } \\
\text { Medium } \\
\text { Medium } \\
\text { Low } \\
\text { Low }\end{array}$ & $\begin{array}{r}0.4 \\
.4 \\
.4 \\
.4 \\
.7\end{array}$ & $\begin{array}{r}-12.0 \\
-9.5 \\
-17.5 \\
-21.5 \\
-19.0\end{array}$ & $\begin{array}{l}4.5 \\
4.25 \\
4.0 \\
6.0 \\
3.0\end{array}$ \\
\hline
\end{tabular}

TABLE 3. - SUMMARY OF PROFILE POWER MEASUREMENTS FROM FLAT PITCH SPEED RUNUPS

\begin{tabular}{|c|c|c|c|c|}
\hline $\begin{array}{c}\text { Flight } \\
\text { number }\end{array}$ & $\begin{array}{c}L W C, \\
\mathrm{gm} / \mathrm{m}^{3}\end{array}$ & $\begin{array}{c}\text { Ambient } \\
\text { temperature, } \\
\mathrm{C}\end{array}$ & $\Delta \mathrm{HP}$ avg & $(\Delta \mathrm{Cdo}) \mathrm{avg}$ \\
\hline $\begin{array}{c}\text { Baseline } \\
\text { A }\end{array}$ & 0.4 & -12.0 & -- & 0.0091 \\
$\mathrm{~B}$ & .4 & -9.5 & 45 & .0099 \\
$\mathrm{E}$ & .7 & -19.0 & 60 & .0104 \\
\hline
\end{tabular}

TABLE 4. - SUMMARY OF HOVER PERFORMANCE MEASUREMENTS

\begin{tabular}{|c|c|c|c|c|c|c|c|}
\hline $\begin{array}{l}\text { Flight } \\
\text { number }\end{array}$ & $\begin{array}{l}\mathrm{LWC}, \\
\mathrm{gm} / \mathrm{m}^{3}\end{array}$ & $\begin{array}{c}\text { Ambient } \\
\text { temperature, } \\
{ }_{C}\end{array}$ & $\begin{array}{l}\text { Time } \\
\text { in cloud, } \\
\text { min }\end{array}$ & $\begin{array}{l}\text { Maximum } \\
\text { ice thickness } \\
\text { at } r / R=0.5, \\
\quad \text { in }\end{array}$ & $\begin{array}{c}\text { Ice } \\
\text { extent, } \\
(r / R)\end{array}$ & $\left(x C_{D^{5}}\right)$ & $\begin{array}{c}\text { Equivalent } \\
\text { standard day } \\
\text { power change, } \\
\text { (shp) }\end{array}$ \\
\hline $\begin{array}{l}A \\
B \\
E\end{array}$ & $\begin{array}{r}0.4 \\
.4 \\
.7\end{array}$ & $\begin{array}{r}-12.0 \\
-9.5 \\
-19.0\end{array}$ & $\begin{array}{l}4.5 \\
4.25 \\
3.0\end{array}$ & $\begin{array}{r}0.2 \\
.3 \\
.4\end{array}$ & $\begin{array}{r}0.75 \\
.65 \\
.92\end{array}$ & $\begin{array}{l}2.4 \\
1.2 \\
2.1\end{array}$ & $\begin{array}{r}+101 \\
+50 \\
+89\end{array}$ \\
\hline
\end{tabular}


OTTAWA SPRAY RIG TEST
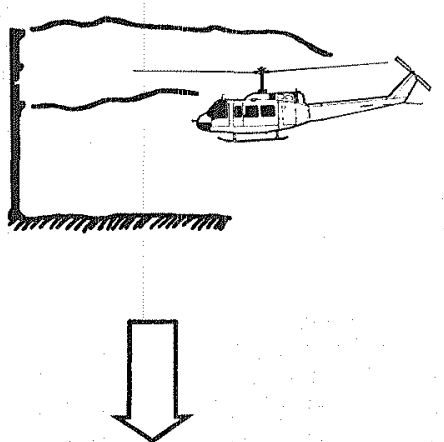

ROTOR PERFORMANCE

MEASUREMENTS

$\mathrm{HP}_{\text {req }}$

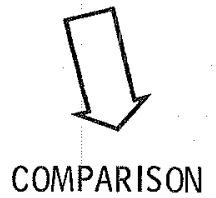

5

ROTOR PERFORMANCE

CALCULATIONS

$\mathrm{HP}_{\text {req }}$
DETAILED ICE SHAPE

DOCUMENTATION
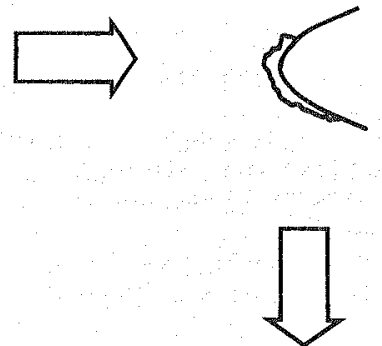

Mo

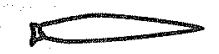

WIND TUNNEL TEST

OF "EQUIVALENT"

2D MODELS

$\mathrm{Cl}, \mathrm{Cd}, \mathrm{Cm}$

Figure 1. - Major elements of HIFT program (phase one).

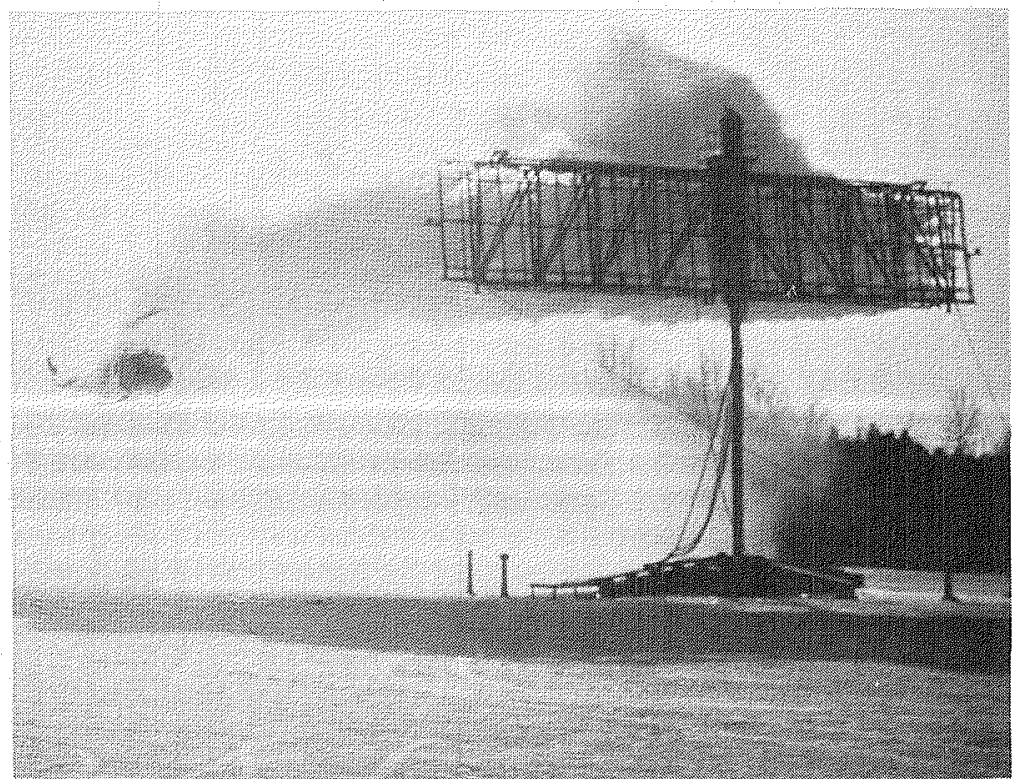

Figure 2. - UH-1H helicopter in Ottawa spray rig. 


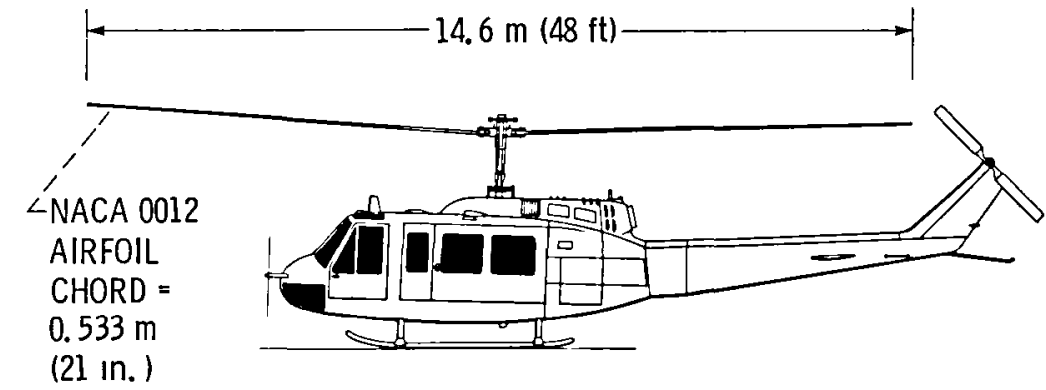

Figure 3. - Schematic of UH-1H helıcopter used in the HIFT program. 


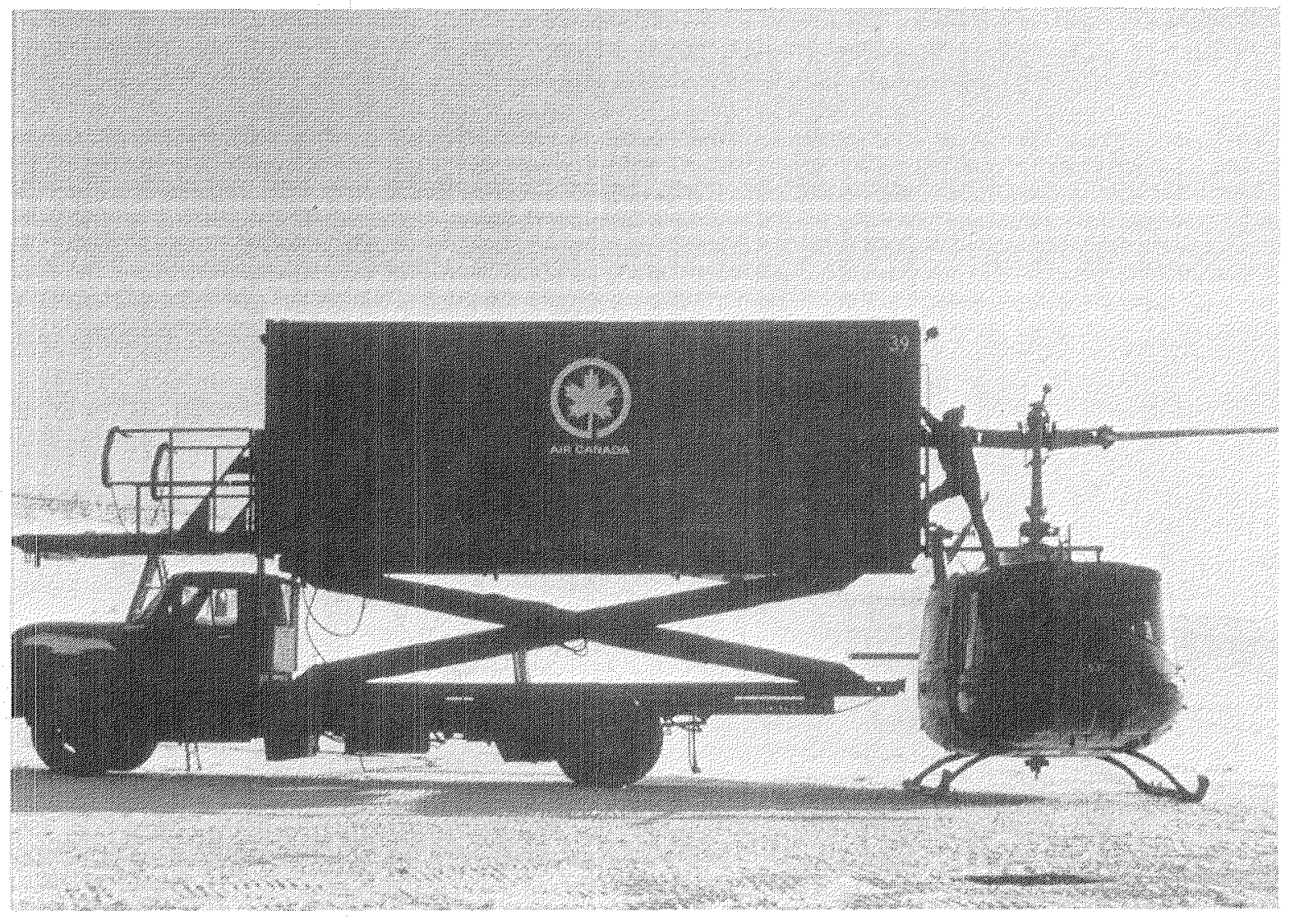

Figure 4. - Helicopter with the rotor ice accretion documentation station. 


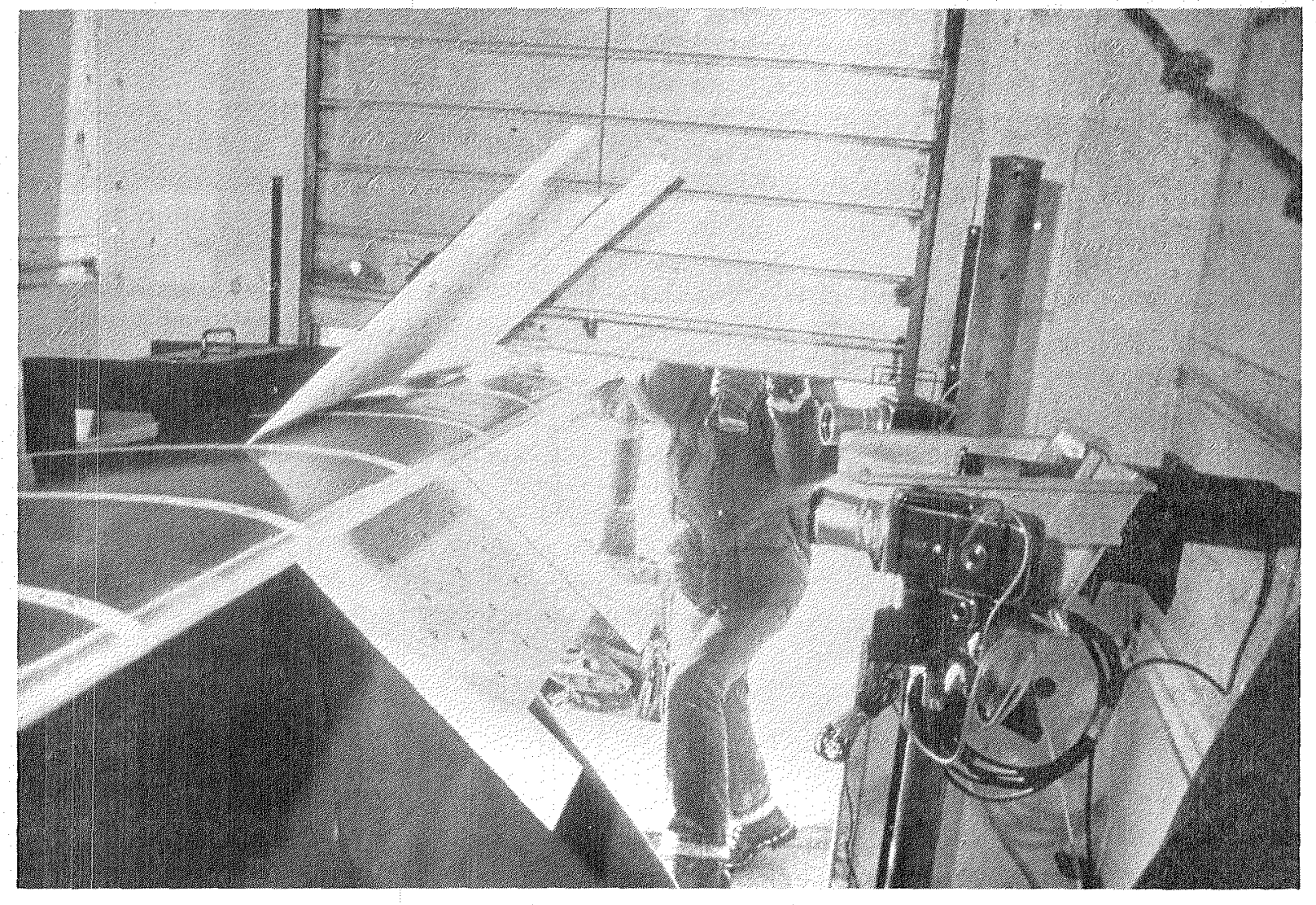

Figure 5. - Stereo photography set up. 


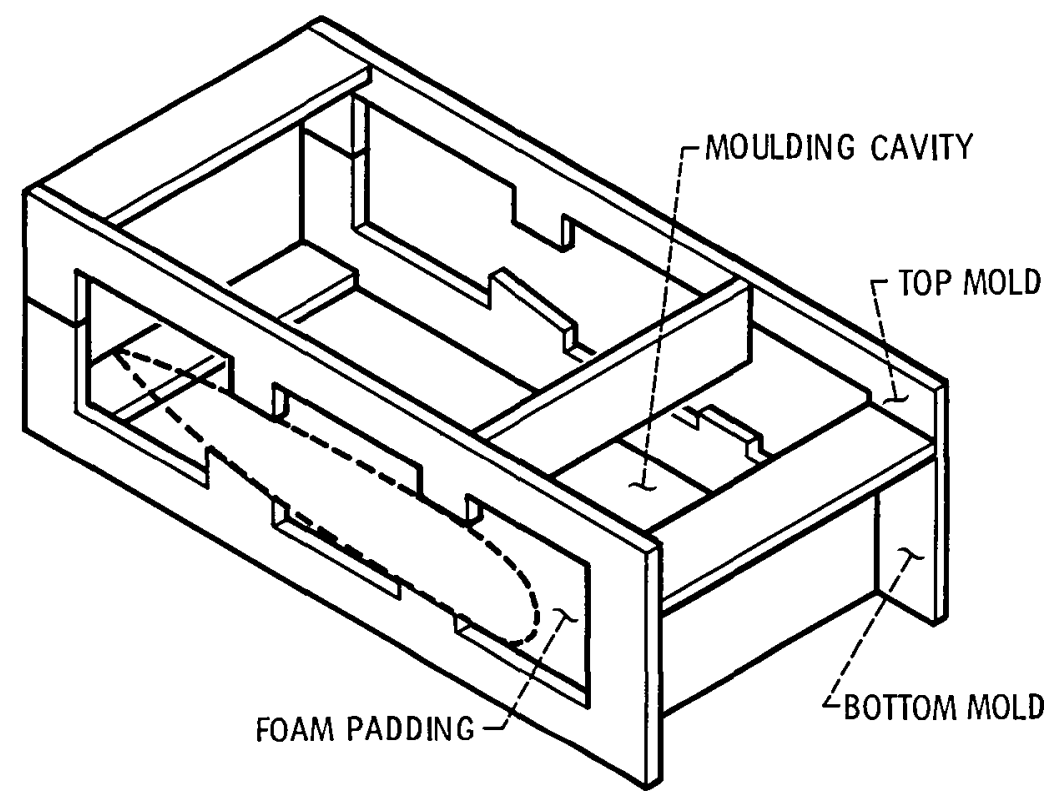

Figure 6. - Mold box detalls. 


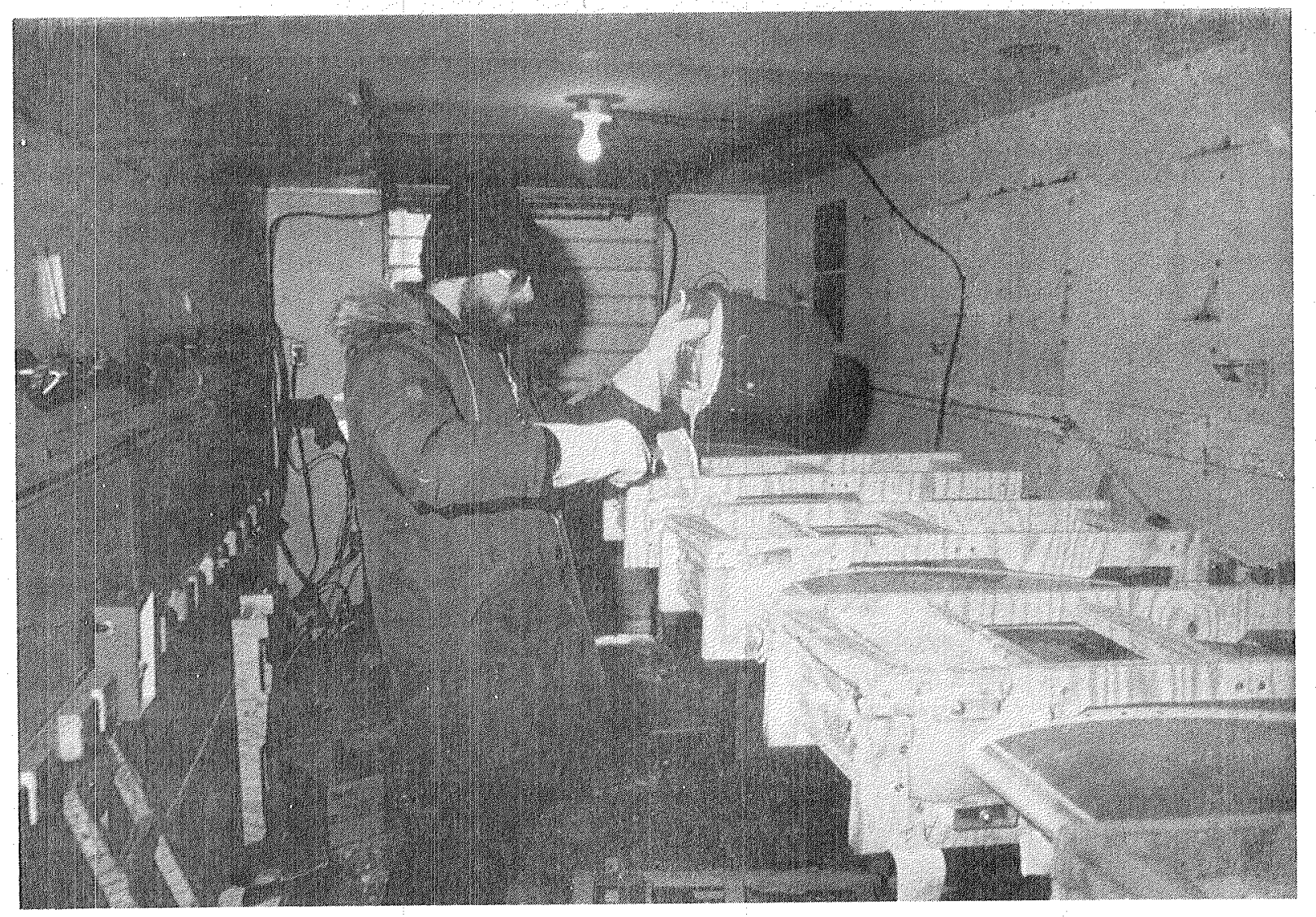

Figure 7. - UH-1H rotor blade with mold boxes attached. 


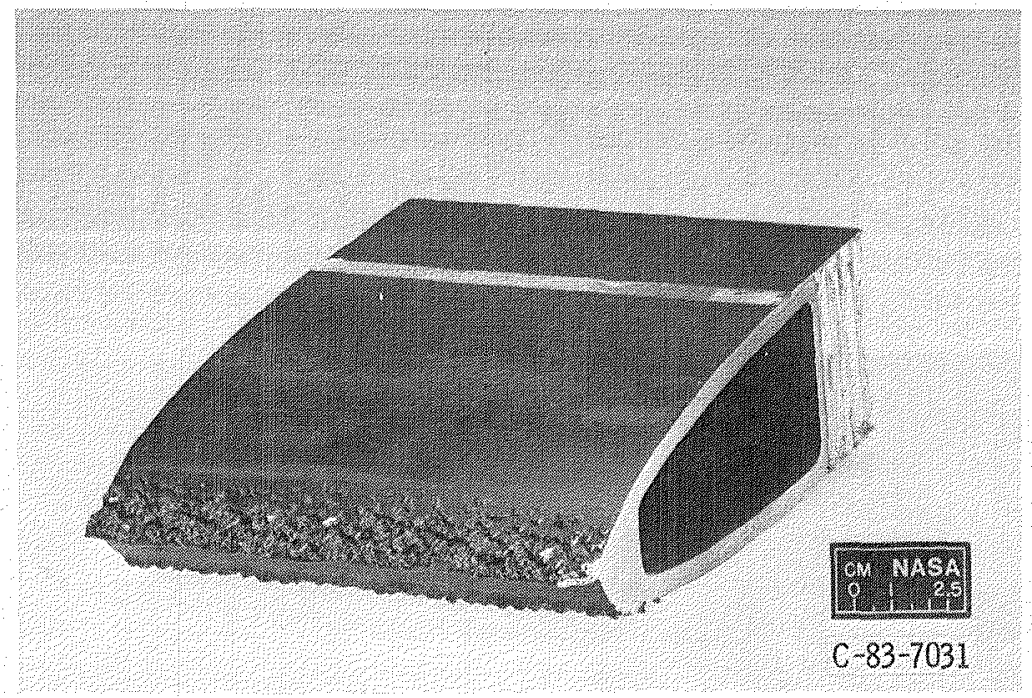

Figure 8. - Epoxy casting affixed to UH-IH rotor section.

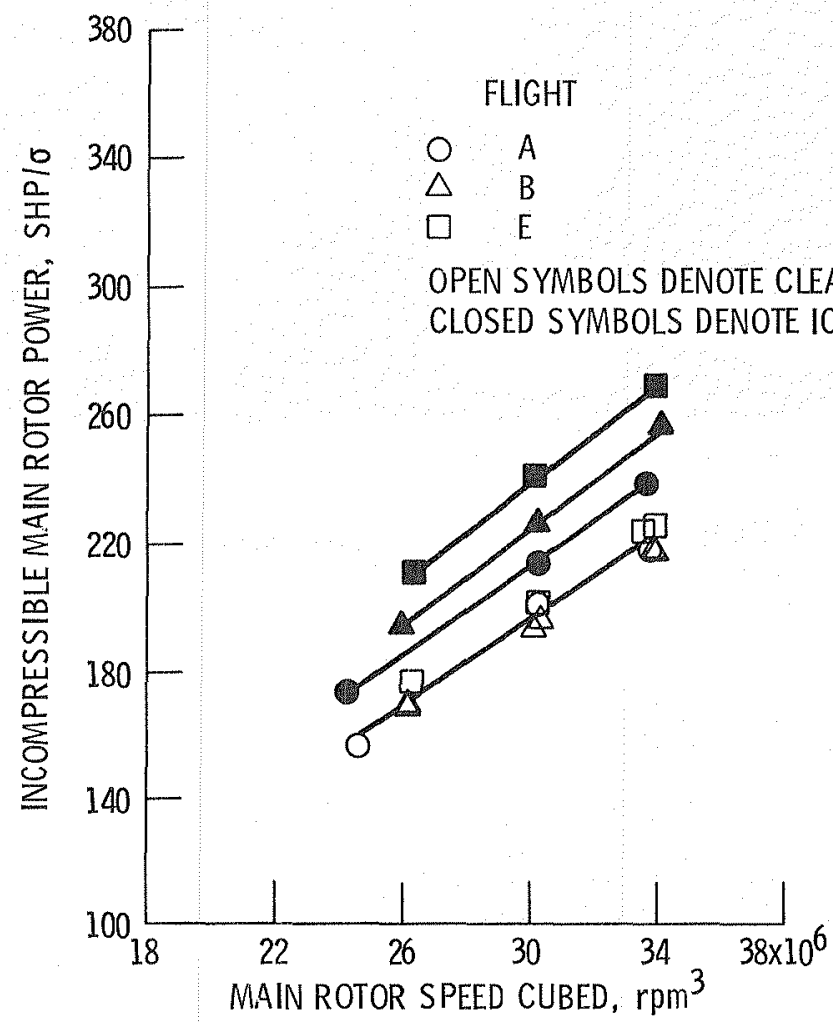

Figure 9. - Incompressible profile power curves (Ref. 5). 

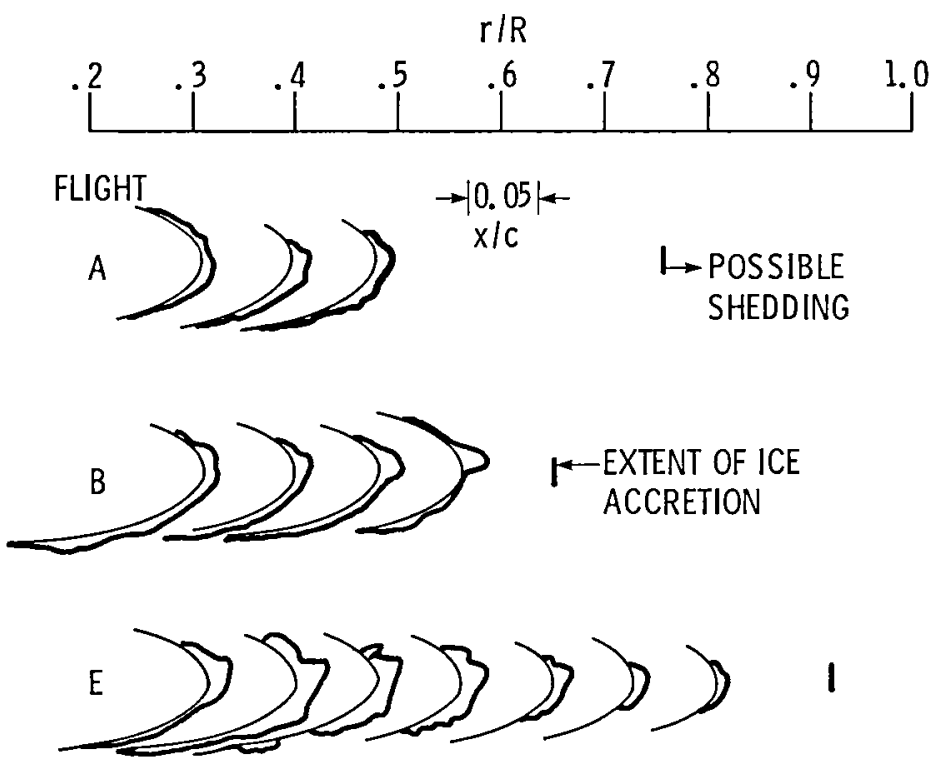

Figure 10. - Rotor Ice accretion tracings for flights $A, B$, and $E$.

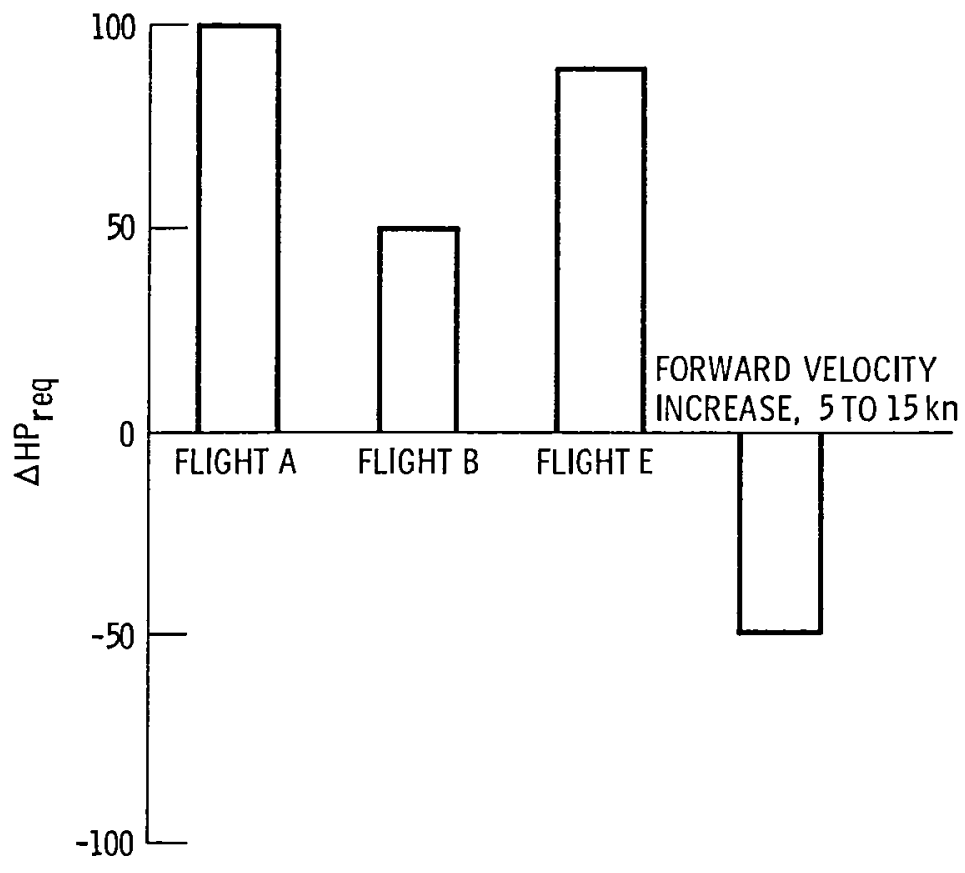

Figure 11. - Comparison of increased horsepower required due to icing with reduced horsepower required due to forward velocity increase. 


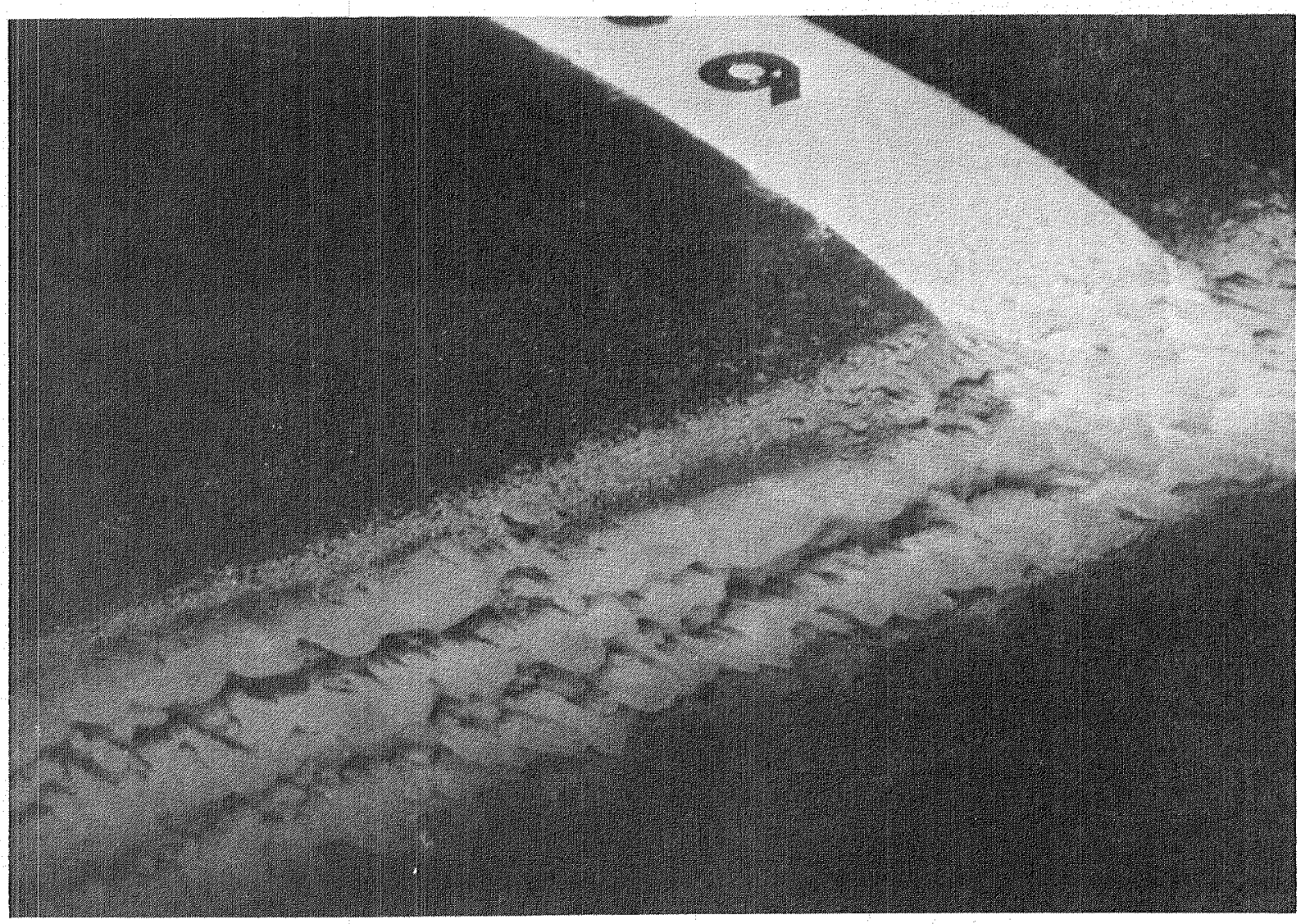

Figure 12. - Photo of typical ice for mation on rotor blade showing three dimensional details (the white stripe is 1 in. wide). (ref. 7) 

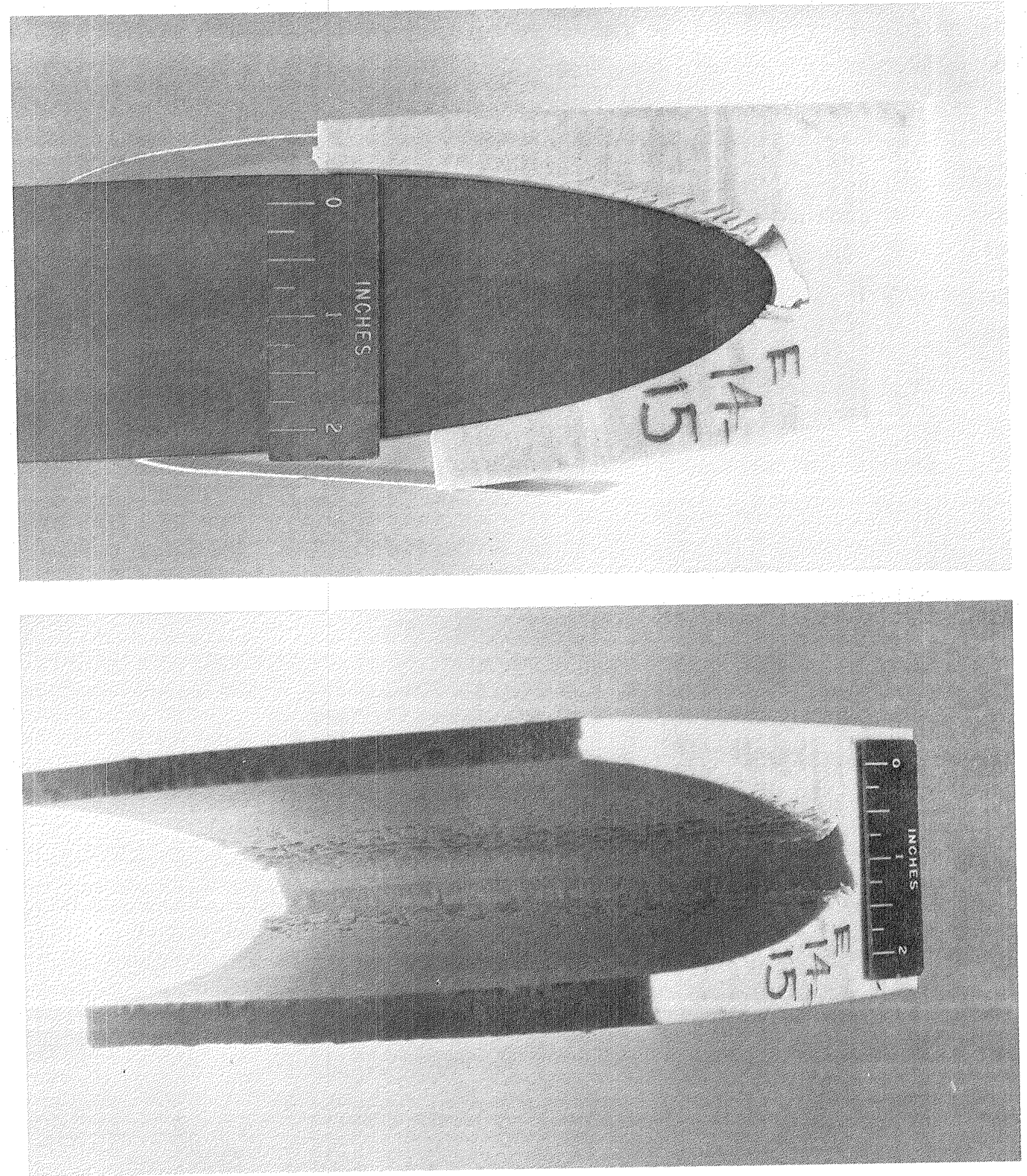

Figure 13. - Typical molds obtained of ice formations. (ref. 7) 


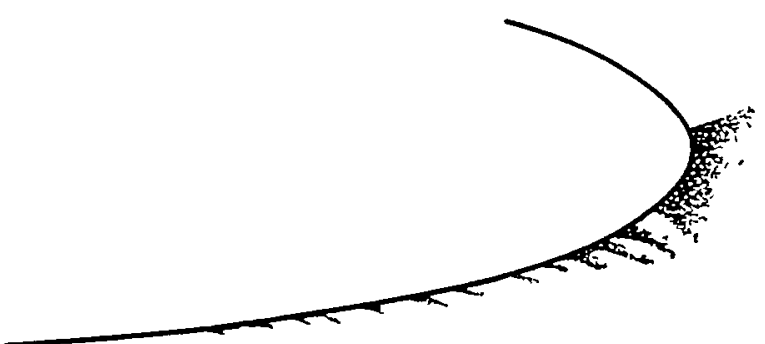

(a) Edge projection of mold.

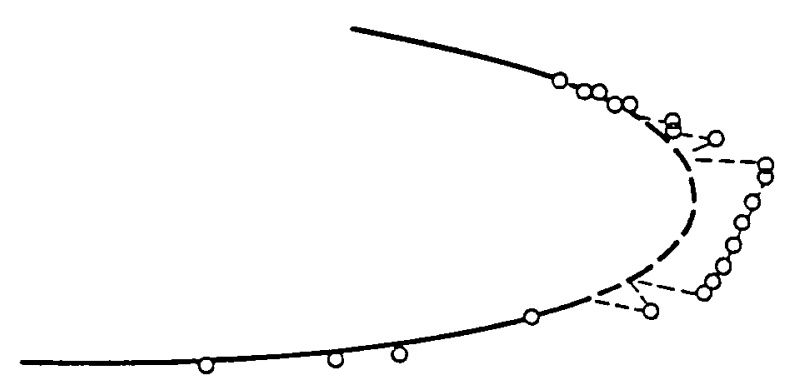

(b) Stereoscopıc photograph.

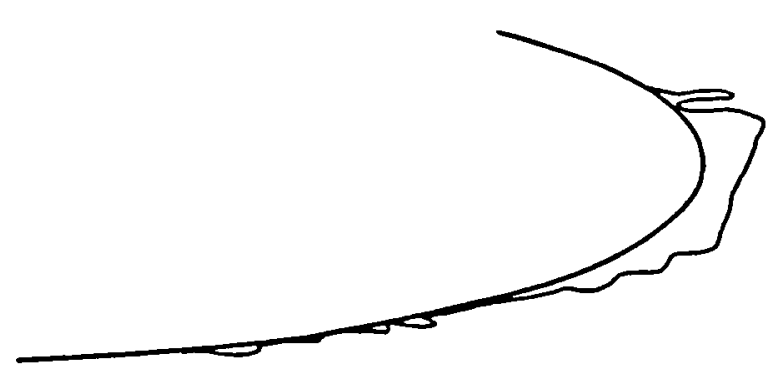

(c) Tracing。

Figure 14. - Comparison of Ice shape documentation techniques. (Flight $E, r / R \approx 0.46$.) 


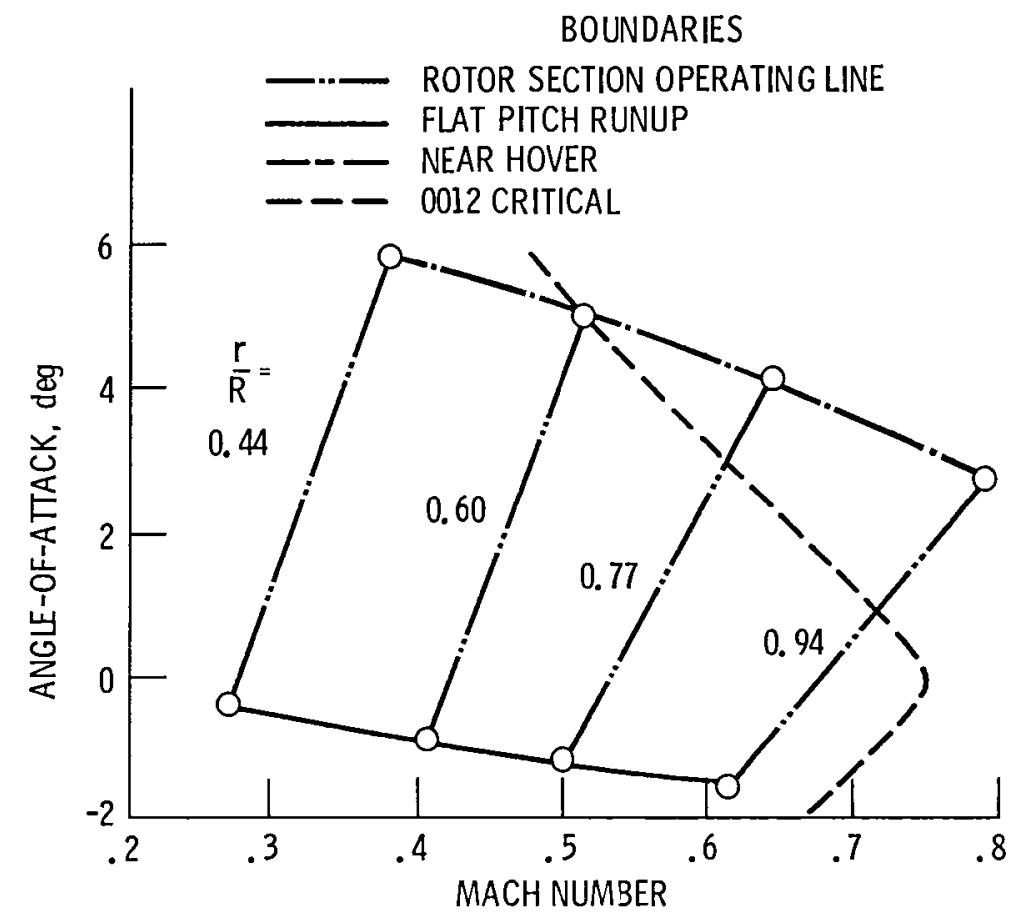

Figure 15. - Rotor section operatıng boundaries (Ref. 15 l. 

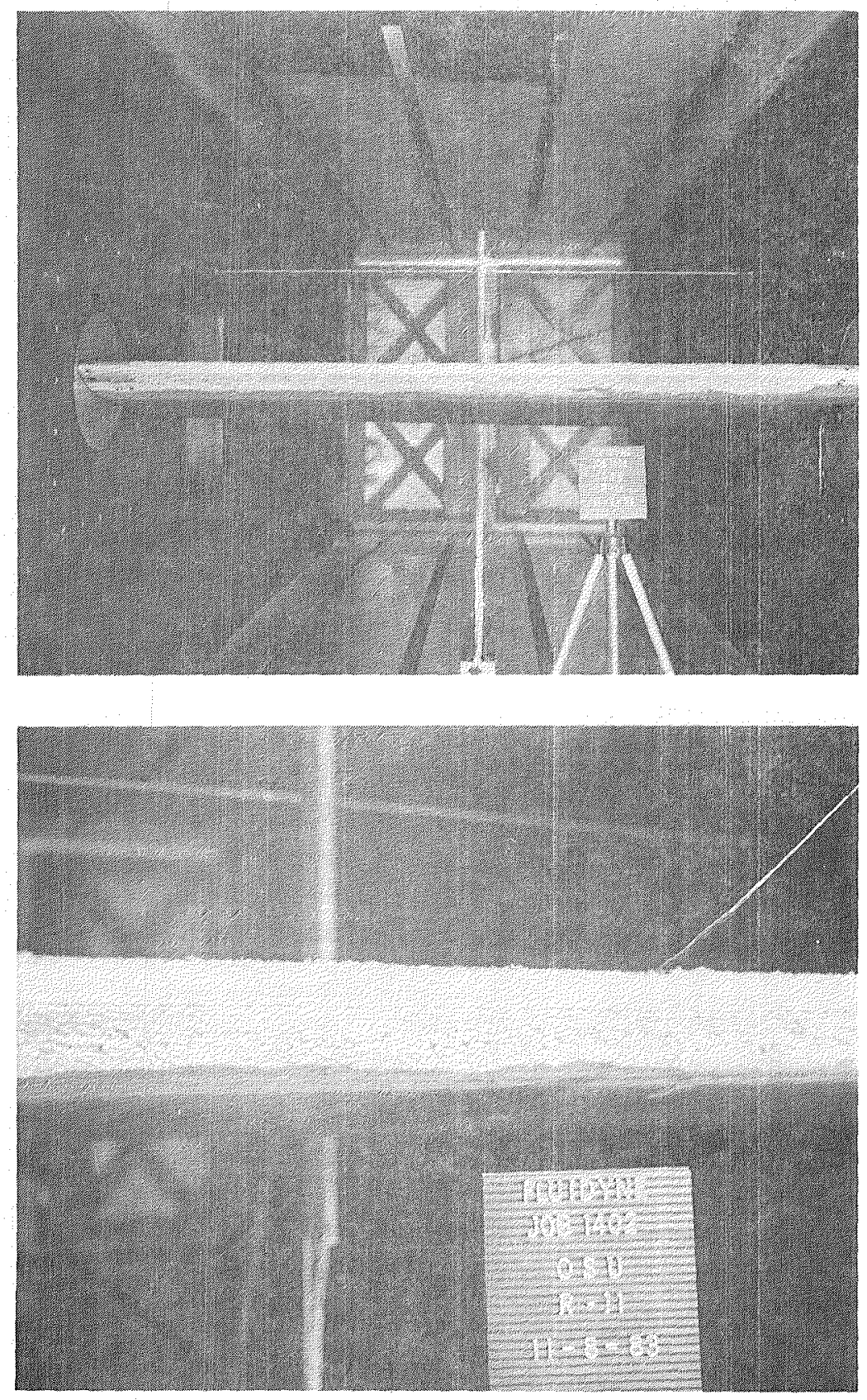

Figure 16. $-\mathrm{UH}-1 \mathrm{H}$ rotor section model with artificial ice accretion installed in Fluidyne wind tunnel. 


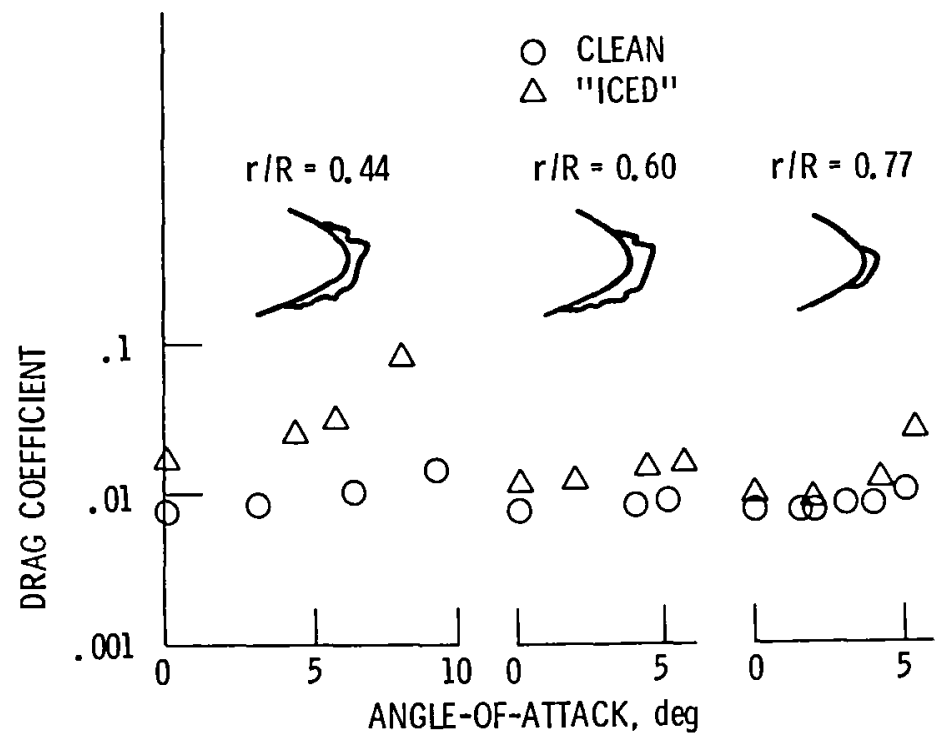

Figure 17. - Dry wind tunnel result for "Iced" aırfoll performance.

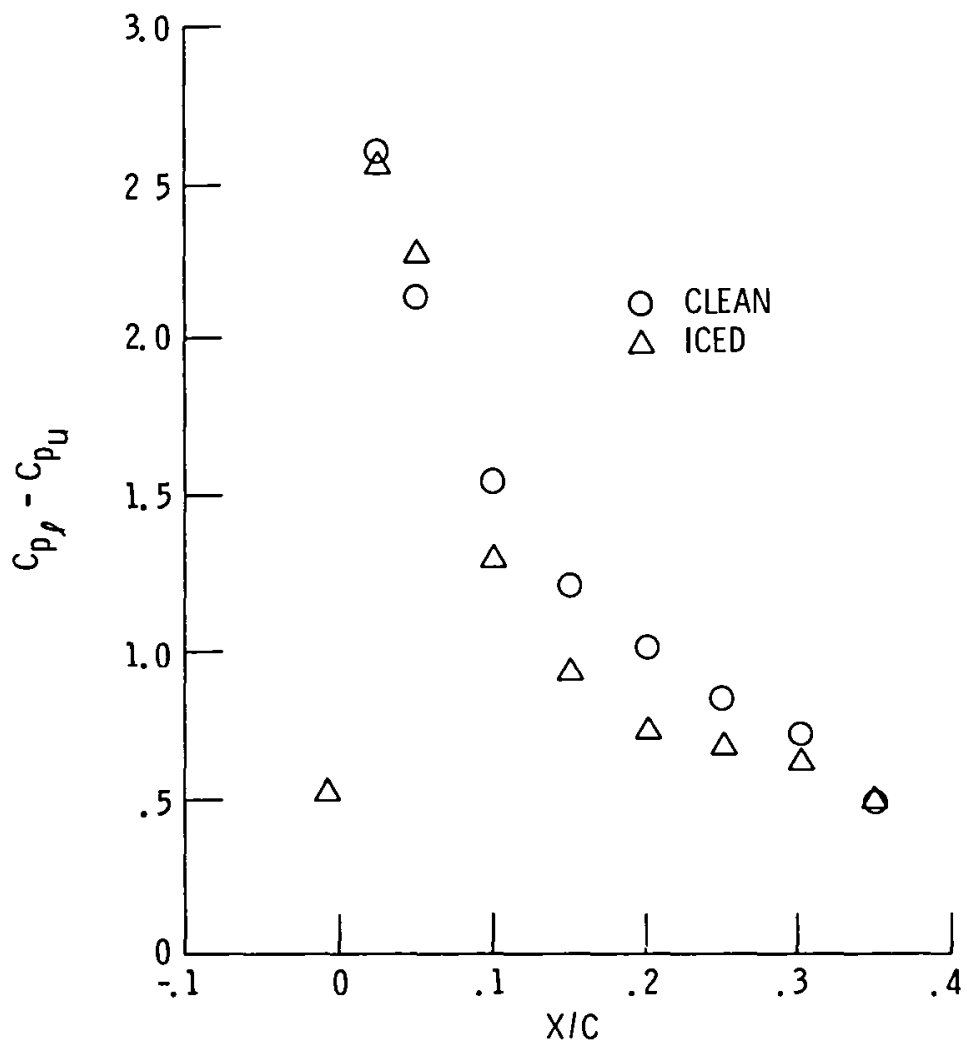

Figure 18. - Surface pressure coefficient differential curve. $M_{\infty}=0.35, a=5.9^{0}, r / R=0.44$. 


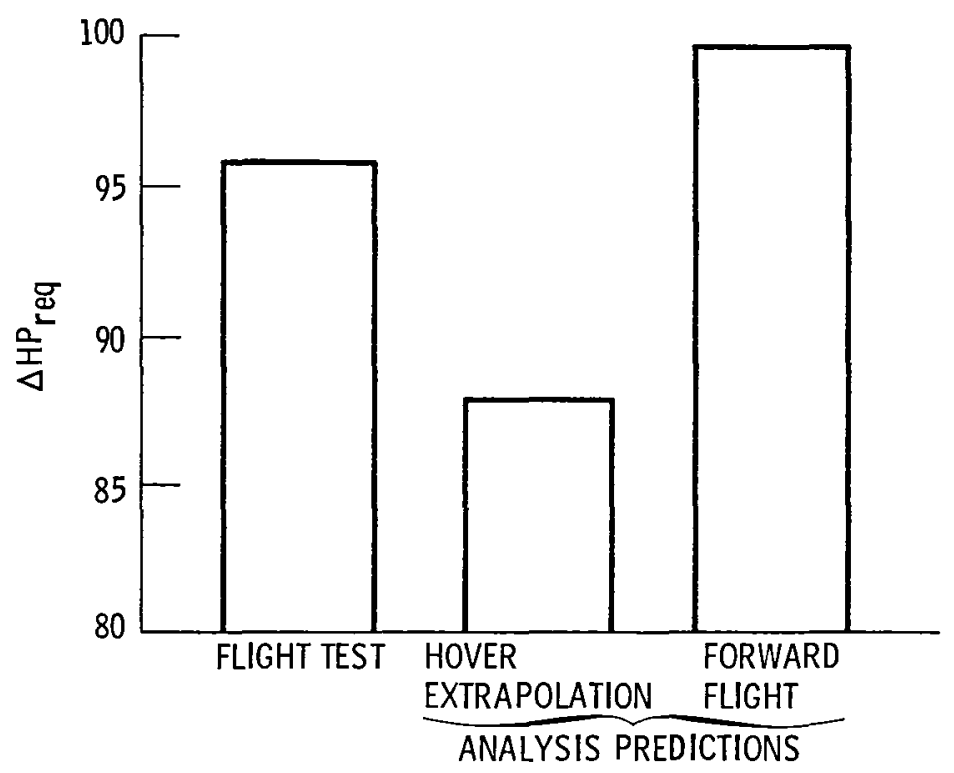

Figure 19. - UH-1H rotor performance degradation due to icıng for flight $\mathrm{E}$ - experımental and predıcted. 


\begin{tabular}{|c|c|c|c|c|}
\hline $\begin{array}{r}1 \text { Report No NASA TM- } 86925 \\
\text { AIAA-85-0338 }\end{array}$ & \multicolumn{2}{|c|}{ 2. Government Accession No } & \multicolumn{2}{|c|}{3 Recipient's Catalog No } \\
\hline \multicolumn{3}{|l|}{4 Title and Subtitle } & \multicolumn{2}{|l|}{5 Report Date } \\
\hline \multicolumn{3}{|c|}{$\begin{array}{l}\text { The UH-IH Helicopter Icing Flight Test Program: An } \\
\text { Overview }\end{array}$} & \multicolumn{2}{|c|}{$\begin{array}{l}6 \text { Performing Organization Code } \\
505-45-45\end{array}$} \\
\hline \multirow{2}{*}{\multicolumn{3}{|c|}{$\begin{array}{l}7 \text { Author(s) } \\
\text { Robert J. Shaw and G. Paul Richter }\end{array}$}} & \multicolumn{2}{|c|}{$\begin{array}{l}8 \text { Performing Organization Report No } \\
\text { E-2421 }\end{array}$} \\
\hline & & & \multicolumn{2}{|l|}{ 10. Work Unit No } \\
\hline \multicolumn{5}{|c|}{9 Performing Organization Name and Address } \\
\hline \multirow{2}{*}{\multicolumn{3}{|c|}{$\begin{array}{l}\text { National Aeronautics and Space Administration } \\
\text { Lewis Research Center } \\
\text { Cleveland, Ohio } 44135\end{array}$}} & \multicolumn{2}{|c|}{11 Contract or Grant No } \\
\hline & & & \multicolumn{2}{|c|}{$\begin{array}{l}13 \text { Type of Report and Period Covered } \\
\text { Technical Memorandum }\end{array}$} \\
\hline \multicolumn{3}{|c|}{$\begin{array}{l}12 \text { Sponsoring Agency Name and Address } \\
\text { National Aeronautics and Space Administration } \\
\text { Washington, D.C. } 20546\end{array}$} & \multicolumn{2}{|c|}{14 Sponsoring Agency Code } \\
\hline \multicolumn{5}{|c|}{$\begin{array}{l}\text { Prepared for the Twenty-third Aerospace Sciences Meeting sponsored by the } \\
\text { American lnstitute of Aeronautics and Astronautics, Reno, Nevada, January 14-17, } \\
198 \mathrm{~b} \text {. }\end{array}$} \\
\hline \multicolumn{5}{|c|}{$\begin{array}{l}\text { An overview is given of the elements of an ongoing joint NASA/Army program to } \\
\text { study the effects of ice accretion on unprotected helicopter rotor aerodynamic } \\
\text { performance. This program integrates flight testing, wind tunnel testing, and } \\
\text { analytical modeling. Results are discussed for helicopter flight testing in the } \\
\text { Canadian NRC hover spray rig facility to measure rotor aero performance degrada- } \\
\text { tion and document rotor ice accretion characteristics. The results of dry wind } \\
\text { tunnel testing of airfoil sections with artificial ice accretions and predictions } \\
\text { of rotor performance degradation using available rotor performance codes and the } \\
\text { wind tunnel data are presented. An alternative approach to conducting future } \\
\text { helicopter icing flight programs is discussed. }\end{array}$} \\
\hline \multicolumn{2}{|l|}{17 Key Words (Suggested by Author(s)) } & \multirow{2}{*}{\multicolumn{3}{|c|}{$\begin{array}{l}18 \text { Distribution Statement } \\
\text { Unclassif red - unlimited } \\
\text { STAR Category } 03\end{array}$}} \\
\hline $\begin{array}{l}\text { Helicopter icing; R } \\
\text { tunnel testing; Ana }\end{array}$ & $\begin{array}{l}\text { ing; Wind- } \\
\text { modeling }\end{array}$ & & & \\
\hline $\begin{array}{r}19 \text { Security Classif (of this report) } \\
\text { Unclas if ied }\end{array}$ & $\begin{array}{r}\text { Security Classif } \\
\text { Ur }\end{array}$ & sified & 21 No of pages & 22 Price* \\
\hline
\end{tabular}


End of Document 